\title{
IMPACT DISTRIBUTION METHODS' USE IN MULTIFUNCTIONAL LIFE CYCLE ASSESSMENTS: A SYSTEMATIC LITERATURE REVIEW
}

\section{O USO DE MÉTODOS DE DISTRIBUIÇÃO DE IMPACTOS EM ACVS DE PROCESSOS MULTIFUNCIONAIS: UMA REVISÃO SISTEMÁTICA DA LITERATURA}

\author{
Marcella Ruschi Mendes Saade 1 \\ University of Campinas, Campinas, São Paulo, Brazil, marcellarms@hotmail.com \\ Maristela Gomes da Silva ${ }^{2}$ \\ Federal University of Espírito Santo, Vitória, Espírito Santo, Brazil, margomes.silva@gmail.com \\ Vanessa Gomes da Silva ${ }^{3}$ \\ University of Campinas, Campinas, São Paulo, Brazil, vangomes@fec.unicamp.br
}

\section{Resumo}

Partitioning loads related to multifunctional processes, which generate more than one product or service (i.e,. function), is a controversial issue within life cycle assessment (LCA). ISO 14044:2006 suggests avoiding allocation through a hierarchic stepwise procedure, through (i) subdividing the multifunctional process into unitary sub-processes with one specific function; or (ii) expanding the system boundaries to include the additional functions related to by-product(s). If the latter steps are not possible, the system's inputs and outputs must be allocated based on a fundamental physical relationship between products. When one is unable to identify such physical relationship, flows must be partitioned as to reflect other relations between products, such as their economic value. This paper aims to delineate a scientific overview of the impact distribution methods' use within LCA practice from 2006 to 2016 . Authors performed a systematic literature review and documented methods' choice frequency within studies published in the considered time frame. Results revealed a lack of consensus among LCA practitioners. Most papers adopt the avoided burden approach (equivalent to system expansion), while the first step proposed in ISO 14044's hierarchy (subdivision) was the least used method. Our examination confirmed that the impact division problem is typically solved by substantially diverging from ISO's theoretical framework, which suggests both an opportunity for reflection and a reformulation need.

Keywords: LCA. Allocation. System expansion. Subdivision. Avoided burden. Systematic literature review.

\begin{abstract}
Resumo
Uma questão controversa em ACV é a escolha do método de distribuição de impactos nos processos multifuncionais, isto é: que geram mais de um produto ou serviço. A ISO 14044:2006 sugere que se tente evitar a alocação, utilizando: (i) divisão do processo multifuncional em dois ou mais subprocessos unitários; ou (ii) expansão do sistema de produto para incluir as funções adicionais relativas aos co-produtos. Caso isto não seja possível, as entradas e saídas do sistema devem ser divididas com base em alguma relação física fundamental entre produtos. Caso a relação física não seja identificada, os fluxos devem ser divididos refletindo outras relações entre produtos, por exemplo, seu valor econômico. Este artigo visa delinear um panorama científico do uso de métodos de distribuição de 2006 a 2016. Para tanto, realizou-se uma revisão sistemática de literatura e documentou-se a frequência de escolha dos métodos nos estudos realizados no periodo considerado. Os resultados revelaram uma falta de consenso entre praticantes de ACV. A maioria dos estudos adota a abordagem do impacto evitado (equivalente à expansão do sistema), enquanto o primeiro passo proposto pela ISO 14044 (subdivisão) foi o método menos usado. Nossa avaliação confirmou que o problema de distribuição de impactos é tipicamente solucionado de forma contrária ao encaminhamento teórico proposto na norma, sugerindo uma oportunidade de reflexão e reformulação.
\end{abstract}

Palavras-chaves: ACV. Alocação. Expansão de sistema. Subdivisão. Revisão sistemática da literatura.

How to cite this article:

SAADE, Marcella Ruschi Mendes; SILVA, Maristela Gomes da; SILVA, Vanessa Gomes da. Impact distribution methods' use in multifunctional Life Cycle Assessments: a systematic literature review. PARC Research in Architecture and Building Construction, Campinas, SP, v. 8, n. 4, p. 272-285, dec. 2017. ISSN 1980-6809. Available at: <https://periodicos.sbu.unicamp.br/ojs/index.php/parc/article/view/8650295>. Date accessed: 08 mar. 2018. doi:https://doi.org/10.20396/parc.v8i4.8650295. 


\section{Introduction}

A multifunctionality problem in LCA arises when a process fulfills one or more function(s) for the investigated product's life cycle, and a different function (or functions) for other product(s) (EKVALL; FINNVEDEN, 2001). Cases like a production process generating multiple products, a waste management process comprising various waste flows, or a recycling process which combines waste management and material production, challenge sharing and distributing material and energy flows across multiple functions.

Due to high co-product incorporation in building materials' manufacturing, the construction sector often faces impact distribution issues. For example, sustainability strategies devised for the cement industry worldwide have been mostly based on clinker substitution to mitigate global warming. LCA provides a robust analysis framework, which enlightens the embedded risks and limitations of single impact-driven policies. Still, multifunctional processes modeling - i.e. impact distribution within them - remains as a highly controversial issue in LCA for its significant influence on studies outcomes (FRISCHKNECHT, 2000; WEIDEMA, 2001; EKVALL; FINNVEDEN, 2001; REAP et al., 2008; SAYAGH et al., 2010). Incomplete impact consideration and contradictory results from varied impact distribution strategies cloud decision-making capacity of affected industries and stakeholders.

ISO 14044 (ISO, 2006a) provides the guideline for performing LCAs. Regarding multifunctionality problemsolving, the standard suggests a stepwise procedure. First, allocation, i.e. the distribution of impacts between a product and co-products based on specific criteria, should be avoided wherever possible, by either dividing multifunctional processes into sub-processes (subdivision) or by expanding the product system to include the co-products' additional functions (system expansion). When allocation cannot be avoided, system inputs and outputs should be divided based on the underlying physical relationships between them. If no physical criteria can easily enable partitioning, then the inputs and outputs should be attributed to reflect other relationships between the products and functions, such as their economic value.

Mass-based allocation is quite straightforward, depending on easily calculated and constant values. However, in many industrial processes, co-product mass generation is significantly high, and mass allocation tends to favor the waste generator, since a large part of the environmental loads is transferred to the activity that uses the co-product.

Economic value-based allocation advocates argue that all industrial activities are guided by economic principles, and to follow that approach for impact distribution would therefore make sense. The most common criticism of using this partitioning criterion refers to its sensitivity to market fluctuations, which hinders results reliability over long periods.

System expansion, as defined by ISO 14044 (2006a), suits best for consequential LCAs (PELLETIER et al., 2015), which consider how to obtain information on changes and environmental impact due to a decision or a change in demand for a product (SCHRIJVERS et al., 2016).

Although not mentioned in ISO 14044 (ISO, 2006a), the 'avoided burden' approach is conceptually equivalent to the system expansion cited in it, and consists of subtracting the environmental loads prevented by co-product recycling from the multifunctional process' loads (TILLMAN et al., 1994; HEIJUNGS; GUINÉE, 2007). This approach improves processes modelling, but still fails to distribute prevented environmental loads across the expanded system components (CHEN et al., 2010), requiring further modeling adjustments (SAADE; SILVA; GOMES, 2015).

At the theoretical level, Weidema and Schmidt (2010), for example, defend that system expansion always respects mass and energy conservation laws, while allocation nearly always fails to do so. According with these authors, as allocation splits the original system into two or more artificial systems, based on the allocation criterion adopted, the only remaining balance would be defined by the given criterion, i.e. when mass regulates allocation, only mass conservation is respected. Conversely, Chen et al (2010) affirmed that system expansion (through the avoided impact approach) does not respect mass conservation laws when the product and co-product are considered together, and chose mass and economic value allocation criteria to assess mineral additions use in concrete manufacturing impacts. Both papers sustain their arguments by using either case-specific (WEIDEMA; SCHMIDT, 2010) or author-defined hypothetical example and equations (CHEN et al., 2010). Both explanations can be contested in different contexts and perspectives.

\section{Methodological approach}

Systematic literature reviews (SLR), widely used in the medical sciences, stand out as a way of synthesizing evidence and allowing researchers to really grasp the status of a research area (WOHLIN, 2014). Systematic reviews consist of an exhaustive summary of the highquality literature on a particular topic. They usually also adopt an additional technique called meta-analysis, which pools together results from a number of different studies (GLASS, 1976), to provide a quantitative (and many times statistical) evaluation of published researches. 
In this paper, following the typical protocol for systematic reviews, the designed research question is: 'How often have the different impact distribution methods been used in multifunctional processes' LCA over the past 10 years?'. We selected Springer database as a search source, for hosting volumes of the 'International Journal of Life Cycle Assessment', the only LCA-specialist international journal available. The time boundary's initial limit refers to the date in which the international LCA standard was last updated (2006). The review ended in the first semester of 2016.

Search keyword string used was: LCA AND allocation OR multifunction* OR avoided burden OR system expansion. Over 1,000 results matched the initial search criteria. The final sample of papers was selected through three exclusion rounds: a title analysis, an abstract analysis and a full paper analysis. Our sample included papers covering attributional and consequential LCAs carried out in any industrial sector. We disregarded grey literature, yet using the 'snowball' approach (LITTEL et al., 2008) to expand the original sample. 147 papers remained, which complied with the predetermined requirements. Then, a data extraction form was built containing all relevant information documented in each paper, to feed the metaanalysis: authors' names and affiliation, date, publishing journal and the method(s) used for impact distribution.

\section{Results presentation and discussion}

Although not described in the international standard, there is, in practice, a distinction between two types of LCA: attributional and consequential. The first is used to learn about the impacts associated to a specific process, to identify improvement opportunities and/or to provide market information (e.g. communicate a product's impact to potential users) (TILLMAN, 2000). The latter is used to obtain information about direct or indirect changes in environmental impacts due to decisions or a change in demand for a product or process (SCHRIJVERS et al., 2016).

From the 147 studies that composed the final sample, only 17 papers worked with consequential LCA. All of them adopted system expansion (SE) and/or the avoided burden approach (AB). These two methods seem to represent the only proper approach to solve impact distribution problems in this type of LCA (Pelletier et al., 2015). As to the remaining literature referring to attributional LCA, we identified not only the methods proposed by ISO 14044 (ISO, 2006a) - subdivision (SD), system expansion, physical causality (PC) and economic value-based allocation (EV) - but also papers that proposed new methods (PM) or ignored impact distribution (NA). As many studies did not follow Heijungs (2014) recommendation to explicitly distinguish 'system expansion' from the 'avoided impact approach', we assessed if (a) the defined functional unit encompassed the co-product(s) function, or (b) avoided impact subtraction occurred; which respectively characterize 'system expansion' and 'avoided burden' approaches. Whenever a paper used multiple, complementary methods, we registered occurrence of all methods.

The number of different approaches registered in the SLR reflects vagueness of ISO 14040 (ISO, 2006b) proposed guidelines. In fact, LCA practice captured in our review (Figure 1) $^{(1)}$ frontally opposes ISO's recommended hierarchy. On one hand, the first alternatives to be tried according to the standardized hierarchy - 'subdivision' (5 papers) and 'system expansion' (10 papers) - showed a discrete and stable use profile. On the other hand, our final sample was dominated by the 'avoided burden approach' (90 papers, derived function $\partial \mathrm{y} / \partial \mathrm{x}=1,0485$ in Figure 1), which is not listed in the standard, followed by physical (62 papers) and economic value (55 papers) allocation, despite the latter being the least recommended approach by ISO. The two allocation approaches present similar trend lines.

Seventy six (76) papers adopted one exclusive impact distribution method. Figure 2 shows that the avoided burden approach's choice dominance still stands out, while subdivision was never individually used. The fact that more than half of the assessed paper sample adopted a single method indicates a breach in ISO compliance in published literature. The international standard clearly states that, when facing a multifunctionality issue, LCA practitioners must perform a sensitivity analysis with more than one distribution method.

Seventeen (17) papers documented construction sectorrelated researches. Their method's choice frequency is depicted in Figure $3^{(2)}$. Although the total number of papers presented a discrete peak in 2013 (analogously to the curves plotted in Figure 1), any trend observation is hindered by the sample's limited size. Still, the top three most used methods' ranking (Figure 1) was maintained in this construction-related excerpt.

Table 1 summarizes our findings, listing each paper and the respective adopted method(s). 
Figure 1 - Multifunctionality modelling solution occurrence since 2006 (occurrence of each method is shown between brackets)

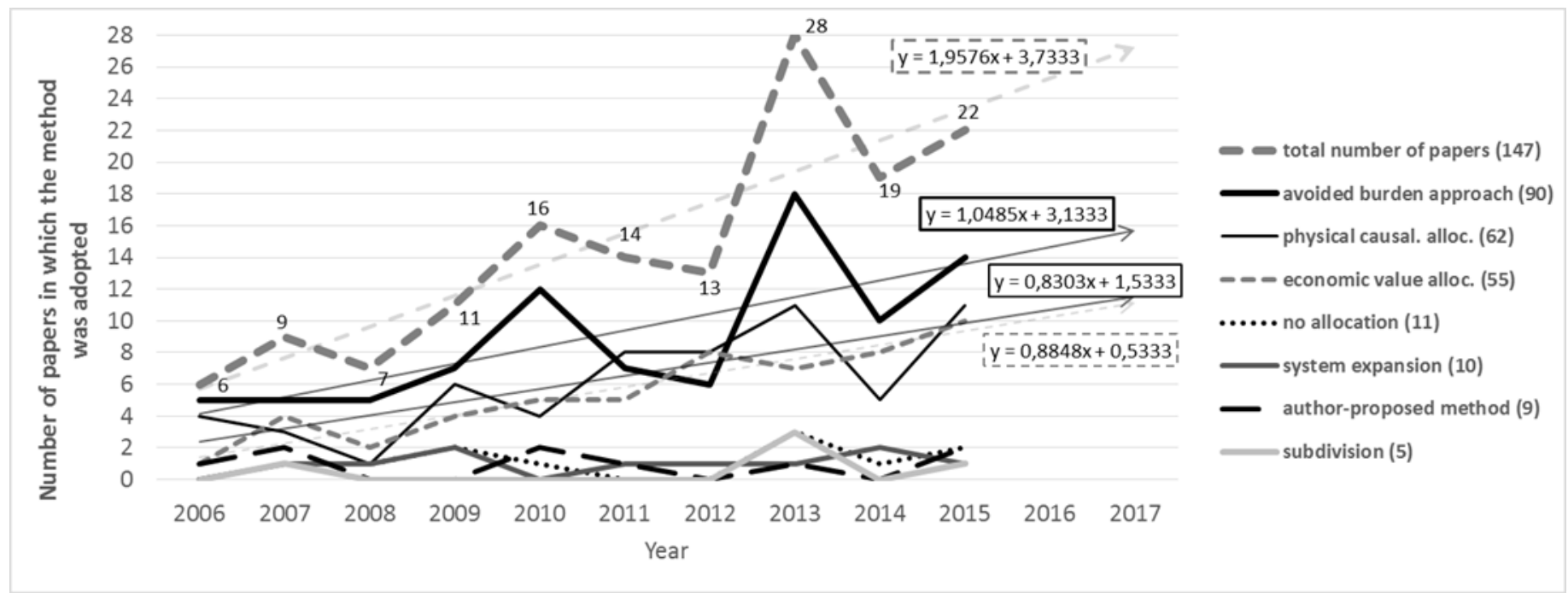

Source: Authors

Figure 2 - Multifunctionality modelling solution occurrence in papers that adopted one method solely since ISO 14040 update in 2006

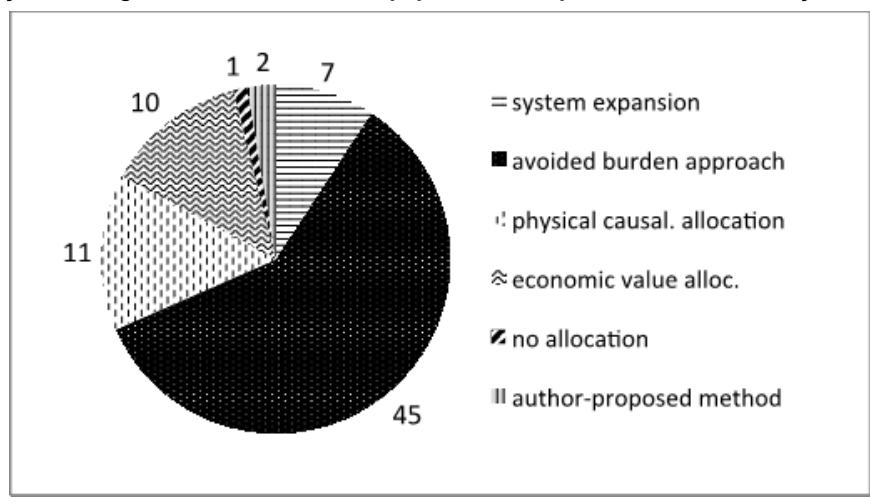

Source: Authors

Figure 3 - Multifunctionality modelling solution occurrence in construction sector-related papers since ISO 14040 update in 2006. Occurrence of each method is shown between brackets

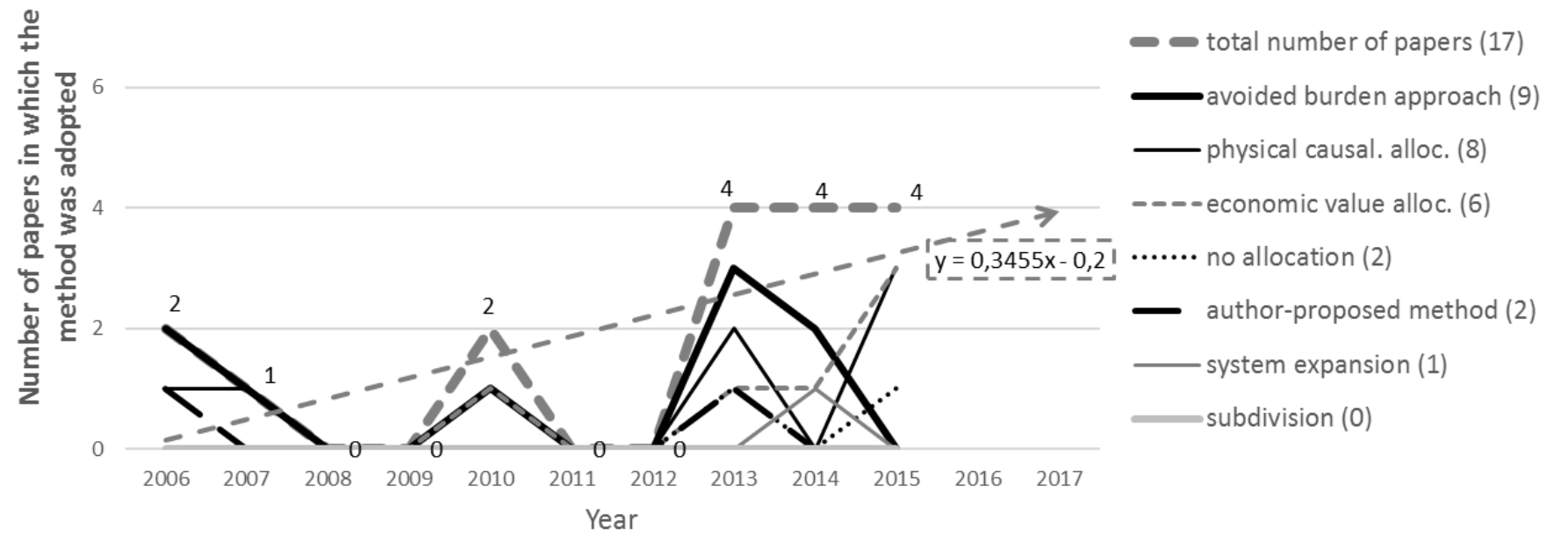

Source: Authors 
Table 1 - Impact distribution methods chosen in each paper

\begin{tabular}{|c|c|c|c|c|c|c|c|}
\hline Author(s) & SD & PC & EV & SE & $\mathrm{AB}$ & PM & NA \\
\hline Adom et al. (2012) & & $\mathrm{X}$ & $\mathrm{X}$ & & & & \\
\hline Aguilera, Guzmán and Alonso (2015) & & & $\mathrm{X}$ & & $\mathrm{X}$ & & \\
\hline Almeida et al. (2014) & & $X$ & & & & & \\
\hline Amores et al. (2013) & & $\mathrm{X}$ & $\mathrm{X}$ & & & & \\
\hline Anastasiou, Liapis and Papayianni (2015) & & & $\mathrm{X}$ & & & & \\
\hline Andreola et al. (2007) & & $X$ & & & $X$ & & \\
\hline Astudillo, Thalwitz and Vollrath (2015) & & $\mathrm{X}$ & $\mathrm{X}$ & & $\mathrm{X}$ & & \\
\hline Bier, Verbeek and Lay (2012) & & $X$ & $\mathrm{X}$ & & $\mathrm{X}$ & & \\
\hline Boldrin, Balzan and Astrup (2013) & & $x$ & & & $x$ & & \\
\hline Cai et al. (2013) & & $\mathrm{X}$ & & & $\mathrm{X}$ & & \\
\hline Chen et al. (2010) & & $\mathrm{X}$ & $\mathrm{X}$ & & & & \\
\hline Choo et al. (2011) & & $X$ & & & $\mathrm{X}$ & & \\
\hline Cleary (2010) & & & & & $\mathrm{X}$ & & \\
\hline Cleary (2014) & & & & & $\mathrm{X}$ & & \\
\hline Cottle and Cowie (2016) & & $\mathrm{X}$ & $\mathrm{X}$ & & $X$ & & \\
\hline Dalgaard et al. (2008) & & & & & $X$ & & \\
\hline Dhaliwal et al. (2014) & & & & & $\mathrm{X}$ & & $\mathrm{X}$ \\
\hline Dias, Arroja and Capela (2007) & $\mathrm{X}$ & $X$ & & & $\mathrm{X}$ & & \\
\hline Dressler, Loewen and Nelles (2012) & & $\mathrm{X}$ & & & $X$ & & \\
\hline Du et al. (2014) & & & & & $X$ & & \\
\hline Eckelman and Chertow (2013) & & & & $\mathrm{X}$ & & & \\
\hline Ferreira et al. (2015) & & $X$ & $\mathrm{X}$ & & & & \\
\hline Fiksel et al. (2011) & & $X$ & & & & & \\
\hline Flysjö et al. (2011) & & $\mathrm{X}$ & $\mathrm{X}$ & & $\mathrm{X}$ & & \\
\hline Gala, Raugei and Fullana-I-Palmer (2015) & & & & & $\mathrm{X}$ & & \\
\hline Galatioto et al. (2015) & & $\mathrm{X}$ & $\mathrm{X}$ & & & & $\mathrm{X}$ \\
\hline Babarenda Gamage et al. (2008) & & & & & $\mathrm{X}$ & & $\mathrm{X}$ \\
\hline Gaudreault, Samson and Stuart (2010) & & $\mathrm{X}$ & & & $\mathrm{X}$ & & $\mathrm{X}$ \\
\hline Gazulla, Raugei and Fullana-I-Palmer (2010) & & & $\mathrm{X}$ & & $\mathrm{X}$ & & \\
\hline Gomes et al. (2013) & & $\mathrm{X}$ & & & $\mathrm{X}$ & & $\mathrm{X}$ \\
\hline González-García et al. (2011) & & $\mathrm{X}$ & & & & & \\
\hline Groot and Borén (2010) & & & $X$ & & $X$ & & \\
\hline Gruber et al. (2015) & & $X$ & & & & & \\
\hline Guinée and Heijungs (2007) & & $\mathrm{X}$ & $\mathrm{X}$ & & & & \\
\hline Guinée, Heijungs and Voet (2009) & & $\mathrm{X}$ & $\mathrm{X}$ & & $\mathrm{X}$ & & \\
\hline Guo and Murphy (2012) & & & $\mathrm{X}$ & & $\mathrm{X}$ & & \\
\hline Habert (2013) & & & & & $\mathrm{X}$ & $\mathrm{X}$ & \\
\hline Herrmann et al. (2012) & & & & & $\mathrm{X}$ & & \\
\hline Höglmeier, Weber-Blaschke and Richter (2014) & & & & $\mathrm{X}$ & & & \\
\hline Hossain et al. (2015) & & $\mathrm{X}$ & & & & & \\
\hline Huang, Spray and Parry (2013) & & $\mathrm{X}$ & $\mathrm{X}$ & & & & \\
\hline Humbert et al. (2009) & & & & & $\mathrm{X}$ & & \\
\hline Jung, Von Der Assen and Bardow (2013) & & $\mathrm{X}$ & & & $X$ & & \\
\hline Karlsdóttir et al. (2015) & $\mathrm{X}$ & $\mathrm{X}$ & & & & & \\
\hline Kendall, Yuan and Brodt (2013) & $\mathrm{X}$ & & $\mathrm{X}$ & & & & \\
\hline Kim and Dale (2006) & & & & & $\mathrm{X}$ & & \\
\hline Kim, Dale and Jenkins (2009) & & $X$ & & & $\mathrm{X}$ & & \\
\hline Kim and Dale (2009) & & $\mathrm{X}$ & & & $\mathrm{X}$ & & \\
\hline Knoeri, Sanyé-Mengual and Althaus (2013) & & & & & $\mathrm{X}$ & & \\
\hline Kuczenski and Geyer (2013) & & & & & $\mathrm{X}$ & & \\
\hline Escobar Lanzuela et al. (2015) & & & & & $\mathrm{X}$ & & \\
\hline Lesage et al. (2007) & & & $\mathrm{X}$ & & $\mathrm{X}$ & & \\
\hline Lundie et al. (2007) & & & & & & $x$ & \\
\hline Luo et al. (2009) & & $\mathrm{X}$ & $\mathrm{X}$ & $\mathrm{X}$ & & & \\
\hline Margallo, Aldaco and Irabien (2014) & & & & & $\mathrm{X}$ & & \\
\hline Mestre and Vogtlander (2013) & & & & & & & $\mathrm{X}$ \\
\hline Moon, Eun and Chung (2006) & & & & & $X$ & $\mathrm{X}$ & \\
\hline Mora et al. (2014) & & & & & $X$ & & \\
\hline Mu et al. (2010) & & & & & $X$ & & \\
\hline Muñoz et al. (2006) & & $\mathrm{X}$ & & & $x$ & & \\
\hline
\end{tabular}


Table 1 - Impact distribution methods chosen in each paper

\begin{tabular}{|c|c|c|c|c|c|c|c|}
\hline Author(s) & SD & PC & EV & SE & $A B$ & PM & NA \\
\hline Muñoz et al. (2009) & & & & & $\mathrm{X}$ & & $\mathrm{X}$ \\
\hline Muñoz et al. (2014) & & & $\mathrm{X}$ & & & & \\
\hline Murphy and Kendall (2013) & $\mathrm{X}$ & $\mathrm{X}$ & $\mathrm{X}$ & & & & \\
\hline Napolano et al. (2014) & & & & & $\mathrm{X}$ & & \\
\hline Nebel, Zimmer and Wegener (2006) & & $X$ & & & $\mathrm{X}$ & & \\
\hline Nguyen and Hermansen (2012) & & $X$ & $\mathrm{X}$ & $X$ & & & \\
\hline Nielsen and Høier (2009) & & & & $\mathrm{X}$ & & & \\
\hline Panichelli, Dauriat and Gnansounou (2009) & & $\mathrm{X}$ & $\mathrm{X}$ & & & & \\
\hline Peters, Iribarren and Dufour (2015) & & & & & $\mathrm{X}$ & & \\
\hline Pires, Chang and Martinho (2011) & & & & & $\mathrm{X}$ & & \\
\hline Pires and Martinho (2013) & & & & & $\mathrm{X}$ & & \\
\hline Prasara-A and Grant (2011) & & & & & $\mathrm{X}$ & & \\
\hline Ridoutt et al. (2012) & & & $\mathrm{X}$ & & & & \\
\hline Saft (2007) & & & & & $\mathrm{X}$ & & \\
\hline Samuel-Fitwi et al. (2013) & & $\mathrm{X}$ & & & $\mathrm{X}$ & & \\
\hline Sandin et al. (2015) & & $\mathrm{X}$ & $\mathrm{X}$ & & $\mathrm{X}$ & $\mathrm{X}$ & $\mathrm{X}$ \\
\hline Scharnhorst et al. (2006) & & $\mathrm{X}$ & & & & & \\
\hline Schmidt and Weidema (2007) & & & & $\mathrm{X}$ & & & \\
\hline Schmidt (2010) & & & $\mathrm{X}$ & & $\mathrm{X}$ & & \\
\hline Shonnard et al. (2015) & & $X$ & & & $x$ & & \\
\hline Siegl, Laaber and Holubar (2011) & & & & & $\mathrm{X}$ & & \\
\hline Siegl, Laaber and Holubar (2012) & & & & & $\mathrm{X}$ & & \\
\hline Silva et al. (2014) & & & $\mathrm{X}$ & & & & \\
\hline Slade, Bauen and Shah (2009) & & $X$ & & & $\mathrm{X}$ & & $X$ \\
\hline Spugnoli and Dainelli (2013) & $\mathrm{X}$ & & & & $\mathrm{X}$ & & \\
\hline Sreejith, Muraleedharan and Arun (2013) & & & & & $\mathrm{X}$ & & \\
\hline Svanes, Vold and Hanssen (2011a) & & $\mathrm{X}$ & $\mathrm{X}$ & & & $\mathrm{X}$ & \\
\hline Svanes, Vold and Hanssen (2011b) & & $\mathrm{X}$ & $\mathrm{X}$ & & & & \\
\hline Svanes and Aronsson (2013) & & $\mathrm{X}$ & $\mathrm{X}$ & & & & \\
\hline Thomassen et al. (2008) & & $X$ & $\mathrm{X}$ & & $\mathrm{X}$ & & \\
\hline Thrane (2006) & & $x$ & $x$ & & $x$ & & \\
\hline Toniolo et al. (2013) & & & & & $\mathrm{X}$ & & $\mathrm{X}$ \\
\hline Tsiropoulos et al. (2014) & & & $\mathrm{X}$ & & $X$ & & \\
\hline Van Der Werf and Nguyen (2015) & & $X$ & $x$ & & & $\mathrm{X}$ & \\
\hline Vázquez-Rowe et al. (2014) & & & & $\mathrm{X}$ & & & \\
\hline Wardenaar et al. (2012) & & $\mathrm{X}$ & $\mathrm{X}$ & & $\mathrm{X}$ & & \\
\hline Werner et al. (2007) & & & $\mathrm{X}$ & & $\mathrm{X}$ & & $\mathrm{X}$ \\
\hline Wiedemann et al. (2015) & & $\mathrm{X}$ & $\mathrm{X}$ & & $\mathrm{X}$ & & \\
\hline Wiloso, Bessou and Heijungs (2015) & & & $\mathrm{X}$ & $\mathrm{X}$ & $x$ & & \\
\hline Xie et al. (2013) & & & & & $x$ & & \\
\hline Zaimes and Khanna (2014) & & $\mathrm{X}$ & $\mathrm{X}$ & & $\mathrm{X}$ & & \\
\hline Zaman (2010) & & & & & $x$ & & \\
\hline Zampori and Dotelli (2014) & & & & & $\mathrm{X}$ & & \\
\hline Zimmermann et al. (2011) & & & $X$ & & & & \\
\hline
\end{tabular}

Poor adherence between ISO's preferred method hierarchy and practice trends is probably related to implementation difficulty. The fact that not all multifunctional processes can be easily split up into unit sub-processes greatly hinders subdivision application. System expansion, on its turn, requires redefinition of system boundaries and functional unit, which might affect the original goal and elongate data collection. Though the scientific robustness of the avoided burden approach is intensively discussed (CHEN et al., 2010; SCHRIJVERS et al., 2016), its dominance suggests that LCA practitioners ultimately value easiness of understanding and use over conceptual superiority.

\section{Final remarks}

The controversy involving multifunctional processes' modeling is extensively documented and discussed in the specialized literature, however, until the finalization of this paper, no research documenting impact distribution methods' choice frequency was identified. This research did not intend to question the appropriateness or superiority of a method, but to outline the scientific overview behind the extensive discussion on multifunctionality within LCA, and to serve as a background or starting point for future discussions on the matter. 
Results illustrate LCA practitioners' preferences to model multifunctional processes. The choice variability detected in the review strengthens the perception of a lack of consensus between researchers and scientists, all the while questioning the appropriateness of the international standard's proposed hierarchy.

Wide and less restrictive guidelines are not uncommon in international standards, which are calibrated to encompass idiosyncratic practices, especially related to impact distribution choices - that predict a certain level of value judgment. However, impact allocation, highlighted in ISO 14044 (ISO, 2006a) as a problem to be avoided, stands out as the second most used method to model multifunctionality in LCA. A decade's worth of application confirmed that the impact division problem is typically solved by substantially diverging from ISO's theoretical framework, which suggests both an opportunity for reflection and a reformulation need.

\section{Acknowledgments}

Authors express their gratitude to $\mathrm{CNPq}$, for the financial support provided.

\section{Notes}

(1) Since the review ended in the first semester of 2016, the number of papers found for that year was smaller than for the previous two years. To better illustrate the trendline, those values were not plotted in Figures 1 and 3 . Those researches and their respective chosen methods can be found in Table 1.

(2) In another systematic literature review, carried out by one of the authors for the Austrian Advanced and Sustainable Sprayed Concrete (ASSpC) project, it became noticeable that, actually, most LCA papers applied to building materials consider co-products as waste. The SLR performed for the present paper was unable to capture that type of LCA due to the keywords' selection, all referring to impact distribution - typically not mentioned in the papers that disregard coproducts' impacts.

\section{References}

ADOM, F. et al. Regional carbon footprint analysis of dairy feeds for milk production in the USA. The International Journal of Life Cycle Assessment, v. 17, n. 5, p. 520-534, 2012. https://doi.org/10.1007/s11367-012-0386-y.

AGUILERA, E.; GUZMÁN, G.; ALONSO, A. Greenhouse gas emissions from conventional and organic cropping systems in Spain. I. Herbaceous crops. Agronomy for Sustainable Development, v. 35, n. 2, p. 713-724, 2015. https://doi.org/10.1007/s13593-014-0267-9.

ALMEIDA, C. et al. Environmental assessment of sardine (Sardina pilchardus) purse seine fishery in Portugal with LCA methodology including biological impact categories. The International Journal of Life Cycle Assessment, v. 19, n. 2, p. 297-306, 2014. https://doi.org/10.1007/s11367-013-0646-5.

AMORES, M. et al. Life cycle assessment of fuel ethanol from sugarcane in Argentina. The International Journal of Life Cycle Assessment, v. 18, n. 7, p. 1344-1357, 2013. https://doi.org/10.1007/s11367-013-0584-2.

ANASTASIOU, E. K.; LIAPIS, A.; PAPAYIANNI, I. Comparative life cycle assessment of concrete road pavements using industrial by-products as alternative materials. Resources, Conservation and Recycling, v. 101, p. 1-8, 2015. https://doi.org/10.1016/j.resconrec.2015.05.009.

ANDREOLA, F. et al. Recycling of EOL CRT glass into ceramic glaze formulations and its environmental impact by LCA approach. The International Journal of Life Cycle Assessment, v. 12, n. 6, p. 448-454, 2007. https://doi.org/10.1065/lca2006.12.289.

ASTUDILLO, M. F.; THALWITZ, G.; VOLLRATH, F. Modern analysis of an ancient integrated farming arrangement: life cycle assessment of a mulberry dyke and pond system. The International Journal of Life Cycle Assessment, v. 20, n. 10, p. 1387-1398, 2015. https://doi.org/10.1007/s11367-015-0950-3.

BABARENDA GAMAGE, G. et al. Life cycle assessment of commercial furniture: a case study of Formway LIFE chair. The International Journal of Life Cycle Assessment, v. 13, n. 5, p. 401-411, 2008. https://doi.org/10.1007/s11367-008-0002-3. 
BIER, J.; VERBEEK, C. R.; LAY, M. An eco-profile of thermoplastic protein derived from blood meal Part 1: allocation issues. The International Journal of Life Cycle Assessment, v. 17, n. 2, p. 208-219, 2012. https://doi.org/10.1007/s11367-011-0349-8

BOLDRIN, A.; BALZAN, A.; ASTRUP, T. Energy and environmental analysis of a rapeseed biorefinery conversion process. Biomass Conversion and Biorefinery, v. 3, n. 2, p. 127-141, 2013. https://doi.org/10.1007/s13399-013-0071-9.

CAI, H. et al. Life-cycle energy use and greenhouse gas emissions of production of bioethanol from sorghum in the United States. Biotechnology for Biofuels, v. 6, n. 1, p. 1-15, 2013. https://doi.org/10.1186/1754-6834-6-141.

CHEN, C. et al. LCA allocation procedure used as an incitative method for waste recycling: An application to mineral additions in concrete. Resources, Conservation and Recycling, v. 54, n. 12, p. 1231-1240, 2010. https://doi.org/10.1016/j.resconrec.2010.04.001.

CHOO, Y. et al. Determination of GHG contributions by subsystems in the oil palm supply chain using the LCA approach. The International Journal of Life Cycle Assessment, v. 16, n. 7, p. 669-681, 2011. https://doi.org/10.1007/s11367-011-0303-9.

CLEARY, J. The incorporation of waste prevention activities into life cycle assessments of municipal solid waste management systems: methodological issues. The International Journal of Life Cycle Assessment, v. 15, n. 6, p. 579-589, 2010. https://doi.org/10.1007/s11367-010-0186-1.

. A life cycle assessment of residential waste management and prevention. The International Journal of Life Cycle Assessment, v. 19, n. 9, p. 1607-1622, 2014. https://doi.org/10.1007/s11367-014-0767-5.

COTTLE, D. J.; COWIE, A. L. Allocation of greenhouse gas production between wool and meat in the life cycle assessment of Australian sheep production. The International Journal of Life Cycle Assessment, p. 1-11, 2016. https://doi.org/10.1007/s11367016-1054-4.

DALGAARD, R. et al. LCA of soybean meal. The International Journal of Life Cycle Assessment, v. 13, n. 3, p. 240-254, 2008. https://doi.org/10.1065/lca2007.06.342.

DHALIWAL, H. et al. A life cycle assessment of packaging options for contrast media delivery: comparing polymer bottle vs. glass bottle. The International Journal of Life Cycle Assessment, v. 19, n. 12, p. 1965-1973, 2014. https://doi.org/10.1007/s11367-014-0795-1.

DIAS, A.; ARROJA, L.; CAPELA, I. Life cycle assessment of printing and writing paper produced in Portugal. The International Journal of Life Cycle Assessment, v. 12, n. 7, p. 521-528, 2007. https://doi.org/10.1065/lca2006.08.266.

DRESSLER, D.; LOEWEN, A.; NELLES, M. Life cycle assessment of the supply and use of bioenergy: impact of regional factors on biogas production. The International Journal of Life Cycle Assessment, v. 17, n. 9, p. 1104-1115, 2012. https://doi.org/10.1007/s11367-012-0424-9.

DU, G. et al. Life cycle assessment as a decision support tool for bridge procurement: environmental impact comparison among five bridge designs. The International Journal of Life Cycle Assessment, v. 19, n. 12, p. 1948-1964, 2014. https://doi.org/10.1007/s11367-014-0797-z.

ECKELMAN, M.; CHERTOW, M. Life cycle energy and environmental benefits of a US industrial symbiosis. The International Journal of Life Cycle Assessment, v. 18, n. 8, p. 1524-1532, 2013. https://doi.org/10.1007/s11367-013-0601-5.

EKVALL, T.; FINNVEDEN, G. Allocation in ISO 14041 - a critical review. Journal of Cleaner Production, v.9, p. 197-208, 2001. https://doi.org/10.1016/S0959-6526(00)00052-4.

ESCOBAR LANZUELA, N. et al. Uncertainty analysis in the environmental assessment of an integrated management system for restaurant and catering waste in Spain. The International Journal of Life Cycle Assessment, v. 20, n. 2, p. 244-262, 2015. https://doi.org/10.1007/s11367-014-0825-z.

FERREIRA, S. et al. Life cycle assessment and valuation of the packaging waste recycling system in Belgium. Journal of Material Cycles and Waste Management, p. 1-11, 2015. https://doi.org/10.1007/s10163-015-0383-x. 
FIKSEL, J. et al. Comparative life cycle assessment of beneficial applications for scrap tires. Clean Technologies and Environmental Policy, v. 13, n. 1, p. 19-35, 2011. https://doi.org/10.1007/s10098-010-0289-1.

FLYSJÖ, A. et al. How does co-product handling affect the carbon footprint of milk? Case study of milk production in New Zealand and Sweden. The International Journal of Life Cycle Assessment, v. 16, n. 5, p. 420-430, 2011. https://doi.org/10.1007/s11367-011-0283-9 .

FRISCHKNECHT, R. Allocation in Life Cycle Inventory Analysis for joint production. International Journal of Life Cycle Assessment, v.5, p. 85-95, 2000. https://doi.org/10.1007/BF02979729.

GALA, A.; RAUGEI, M.; FULLANA-I-PALMER, P. Introducing a new method for calculating the environmental credits of endof-life material recovery in attributional LCA. The International Journal of Life Cycle Assessment, v. 20, n. 5, p. 645-654, 2015. https://doi.org/10.1007/s11367-015-0861-3.

GALATIOTO, F. et al. Traffic modelling in system boundary expansion of road pavement life cycle assessment. Transportation Research Part D: Transport and Environment, v. 36, n. 0, p. 65-75, 2015. https://doi.org/10.1016/j.trd.2015.02.007.

GAUDREAULT, C.; SAMSON, R.; STUART, P. Energy decision making in a pulp and paper mill: selection of LCA system boundary. The International Journal of Life Cycle Assessment, v. 15, n. 2, p. 198-211, 2010. https://doi.org/10.1007/s11367009-0125-1.

GAZULLA, C.; RAUGEI, M.; FULLANA-I-PALMER, P. Taking a life cycle look at crianza wine production in Spain: where are the bottlenecks? The International Journal of Life Cycle Assessment, v. 15, n. 4, p. 330-337, 2010.

https://doi.org/10.1007/s11367-010-0173-6.

GLASS, G.V. Primary, secondary, and meta-analysis of research. Educational Researcher, v.5, n. 10, p. 3-8, 1976.

http://www.jstor.org/stable/1174772.

GOMES, F. et al. Adaptation of environmental data to national and sectorial context: application for reinforcing steel sold on the French market. The International Journal of Life Cycle Assessment, v. 18, n. 5, p. 926-938, 2013. https://doi.org/10.1007/s11367-013-0558-4.

GONZÁLEZ-GARCÍA, S. et al. Combined application of LCA and eco-design for the sustainable production of wood boxes for wine bottles storage. The International Journal of Life Cycle Assessment, v. 16, n. 3, p. 224-237, 2011.

https://doi.org/10.1007/s11367-011-0261-2.

GROOT, W.; BORÉN, T. Life cycle assessment of the manufacture of lactide and PLA biopolymers from sugarcane in Thailand. The International Journal of Life Cycle Assessment, v. 15, n. 9, p. 970-984, 2010. https://doi.org/10.1007/s11367-010-0225-y.

GRUBER, L. M. et al. LCA study of unconsumed food and the influence of consumer behavior. The International Journal of Life Cycle Assessment, p. 1-12, 2015. https://doi.org/10.1007/s11367-015-0933-4.

GUINÉE, J.; HEIJUNGS, R. Calculating the influence of alternative allocation scenarios in fossil fuel chains. The International Journal of Life Cycle Assessment, v. 12, n. 3, p. 173-180, 2007. https://doi.org/10.1065/lca2006.06.253.

GUINÉE, J. B.; HEIJUNGS, R.; VOET, E. A greenhouse gas indicator for bioenergy: some theoretical issues with practical implications. The International Journal of Life Cycle Assessment, v. 14, n. 4, p. 328-339, 2009. https://doi.org/10.1007/s11367009-0080-x.

GUO, M.; MURPHY, R. J. Is There a Generic Environmental Advantage for Starch-PVOH Biopolymers Over Petrochemical Polymers? Journal of Polymers and the Environment, v. 20, n. 4, p. 976-990, 2012. https://doi.org/10.1007/s10924-012-0489-3.

HABERT, G. A method for allocation according to the economic behaviour in the EU-ETS for by-products used in cement industry. The International Journal of Life Cycle Assessment, v. 18, n. 1, p. 113-126, 2013. https://doi.org/10.1007/s11367-0120464-1.

HEIJUNGS, R.; GUINÉE, J. B. Allocation and 'what-if' scenarios in life cycle assessment of waste management systems. Waste Management, v. 27, pp. 997-1005, 2007. https://doi.org/10.1016/j.wasman.2007.02.013. 
HEIJUNGS, R. Ten easy lessons for good communication of LCA. International Journal of Life Cycle Assessment, v. 19, pp. 473-476, 2014. https://doi.org/10.1007/s11367-013-0662-5.

HERRMANN, I. T. et al. Potential for optimized production and use of rapeseed biodiesel. Based on a comprehensive real-time LCA case study in Denmark with multiple pathways. The International Journal of Life Cycle Assessment, v. 18, n. 2, p. 418430, 2012. https://doi.org/10.1007/s11367-012-0486-8.

HOSSAIN, M. U. et al. Evaluation of environmental friendliness of concrete paving eco-blocks using LCA approach. The International Journal of Life Cycle Assessment, v. 21, n. 1, p. 70-84, 2015. https://doi.org/10.1007/s11367-015-0988-2.

HUANG, Y.; SPRAY, A.; PARRY, T. Sensitivity analysis of methodological choices in road pavement LCA. The International Journal of Life Cycle Assessment, v. 18, n. 1, p. 93-101, 2013. https://doi.org/10.1007/s11367-012-0450-7.

HUMBERT, S. et al. Life cycle assessment of two baby food packaging alternatives: glass jars vs. plastic pots. The International Journal of Life Cycle Assessment, v. 14, n. 2, p. 95-106, 2009. https://doi.org/10.1007/s11367-008-0052-6.

HÖGLMEIER, K.; WEBER-BLASCHKE, G.; RICHTER, K. Utilization of recovered wood in cascades versus utilization of primary wood - a comparison with life cycle assessment using system expansion. The International Journal of Life Cycle Assessment, v. 19, n. 10, p. 1755-1766, 2014. https://doi.org/10.1007/s11367-014-0774-6.

ISO- INTERNATIONAL ORGANIZATION FOR STANDARDIZATION. ISO 14044: Environmental Management - Life Cycle Assessment - Requirements and Guidelines. Switzerland, 2006a.

. ISO 14040: Environmental Management - Life cycle principles and Framework. Switzerland, $2006 \mathrm{~b}$.

JUNG, J.; VON DER ASSEN, N.; BARDOW, A. Comparative LCA of multi-product processes with non-common products: a systematic approach applied to chlorine electrolysis technologies. The International Journal of Life Cycle Assessment, v. 18, n. 4, p. 828-839, 2013. https://doi.org/10.1007/s11367-012-0531-7.

KARLSDÓTTIR, M. et al. Life cycle inventory of a flash geothermal combined heat and power plant located in Iceland. The International Journal of Life Cycle Assessment, v. 20, n. 4, p. 503-519, 2015. https://doi.org/10.1007/s11367-014-0842-y.

KENDALL, A.; YUAN, J.; BRODT, S. Carbon footprint and air emissions inventories for US honey production: case studies. The International Journal of Life Cycle Assessment, v. 18, n. 2, p. 392-400, 2013. https://doi.org/10.1007/s11367-012-0487-7.

KIM, S.; DALE, B.. Ethanol Fuels: E10 or E85 - Life Cycle Perspectives (5 pp). The International Journal of Life Cycle Assessment, v. 11, n. 2, p. 117-121, 2006. https://doi.org/10.1065/lca2005.02.201.

. Regional variations in greenhouse gas emissions of biobased products in the United States - corn-based ethanol and soybean oil. The International Journal of Life Cycle Assessment, v. 14, n. 6, p. 540-546, 2009. https://doi.org/10.1007/s11367009-0106-4.

KIM, S.; DALE, B.; JENKINS, R. Life cycle assessment of corn grain and corn stover in the United States. The International Journal of Life Cycle Assessment, v. 14, n. 2, p. 160-174, 2009. https://doi.org/10.1007/s1 1367-008-0054-4.

KNOERI, C.; SANYÉ-MENGUAL, E.; ALTHAUS, H.-J. Comparative LCA of recycled and conventional concrete for structural applications. The International Journal of Life Cycle Assessment, v. 18, n. 5, p. 909-918, 2013. https://doi.org/10.1007/s11367012-0544-2.

KUCZENSKI, B.; GEYER, R. PET bottle reverse logistics - environmental performance of California's CRV program. The International Journal of Life Cycle Assessment, v. 18, n. 2, p. 456-471, 2013. https://doi.org/10.1007/s11367-012-0495-7.

LESAGE, P. et al. Environmental assessment of brownfield rehabilitation using two different life cycle inventory models. The International Journal of Life Cycle Assessment, v. 12, n. 7, p. 497-513, 2007. https://doi.org/10.1065/lca2006.10.279.2.

LITTEL, J. H.; CORCORAN, J.; PILLA, V. Systematic reviews and meta-analysis. Nova Iorque: Oxford University Press, 2008. 
LUNDIE, S. et al. Generation of an Industry-specific Physico-chemical Allocation Matrix. Application in the Dairy Industry and Implications for Systems Analysis (9 pp). The International Journal of Life Cycle Assessment, v. 12, n. 2, p. 109-117, 2007. https://doi.org/10.1065/lca2005.10.228.

LUO, L. et al. Allocation issues in LCA methodology: a case study of corn stover-based fuel ethanol. The International Journal of Life Cycle Assessment, v. 14, n. 6, p. 529-539, 2009. https://doi.org/10.1007/s11367-009-0112-6.

MARGALLO, M.; ALDACO, R.; IRABIEN, Á. Environmental management of bottom ash from municipal solid waste incineration based on a life cycle assessment approach. Clean Technologies and Environmental Policy, v. 16, n. 7, p. 1319-1328, 2014. https://doi.org/10.1007/s10098-014-0761-4.

MESTRE, A.; VOGTLANDER, J. Eco-efficient value creation of cork products: an LCA-based method for design intervention. Journal of Cleaner Production, v. 57, n. 0, p. 101-114, 2013. https://doi.org/10.1016/j.jclepro.2013.04.023.

MOON, J.-M.; EUN, J.-H.; CHUNG, J.-S. Allocation of Process Gases Generated from Integrated Steelworks by an Improved System Expansion Method (7 pp). The International Journal of Life Cycle Assessment, v. 11, n. 4, p. 247-253, 2006. https://doi.org/10.1065/lca2004.12.197.

MORA, M. et al. A methodological improvement for assessing petrochemical projects through life cycle assessment and eco-costs. The International Journal of Life Cycle Assessment, v. 19, n. 3, p. 517-531, 2014. https://doi.org/10.1007/s11367-013-0660-7.

MU, D. et al. Comparative Life Cycle Assessment of Lignocellulosic Ethanol Production: Biochemical Versus Thermochemical Conversion. Environmental Management, v. 46, n. 4, p. 565-578, 2010. https://doi.org/10.1007/s00267-010-9494-2.

MURPHY, C. W.; KENDALL, A. Life cycle inventory development for corn and stover production systems under different allocation methods. Biomass and Bioenergy, v. 58, n. 0, p. 67-75, 2013. https://doi.org/10.1016/j.biombioe.2013.08.008.

MUÑOZ, I. et al. Life cycle assessment of bio-based ethanol produced from different agricultural feedstocks. The International Journal of Life Cycle Assessment, v. 19, n. 1, p. 109-119, 2014. https://doi.org/10.1007/s11367-013-0613-1.

LCA and ecodesign in the toy industry: case study of a teddy bear incorporating electric and electronic components. The International Journal of Life Cycle Assessment, v. 14, n. 1, p. 64-72, 2009. https://doi.org/10.1007/s11367-008-0044-6.

Using LCA to Assess Eco-design in the Automotive Sector: Case Study of a Polyolefinic Door Panel (12 pp). The International Journal of Life Cycle Assessment, v. 11, n. 5, p. 323-334, 2006. https://doi.org/10.1065/lca2005.05.207.

NAPOLANO, L. et al. LCA-based study on structural retrofit options for masonry buildings. The International Journal of Life Cycle Assessment, v. 20, n. 1, p. 23-35, 2014. https://doi.org/10.1007/s11367-014-0807-1.

NEBEL, B.; ZIMMER, B.; WEGENER, G. Life Cycle Assessment of Wood Floor Coverings - A Representative Study for the German Flooring Industry (11 pp). The International Journal of Life Cycle Assessment, v. 11, n. 3, p. 172-182, 2006. https://doi.org/10.1065/lca2004.10.187.

NGUYEN, T. L. T.; HERMANSEN, J. E. System expansion for handling co-products in LCA of sugar cane bio-energy systems: GHG consequences of using molasses for ethanol production. Applied Energy, v. 89, n. 1, p. 254-261, 2012. https://doi.org/10.1016/j.apenergy.2011.07.023.

NIELSEN, P.; HØIER, E. Environmental assessment of yield improvements obtained by the use of the enzyme phospholipase in mozzarella cheese production. The International Journal of Life Cycle Assessment, v. 14, n. 2, p. 137-143, 2009. https://doi.org/10.1007/s11367-008-0048-2.

PANICHELLI, L.; DAURIAT, A.; GNANSOUNOU, E. Life cycle assessment of soybean-based biodiesel in Argentina for export. The International Journal of Life Cycle Assessment, v. 14, n. 2, p. 144-159, 2009. https://doi.org/10.1007/s11367-008-0050-8.

PELLETIER, N.; ARDENTE, F.; BRANDÃO, M.; DE CAMILLIS, C.; PENNINGTON, D. Rationales for and limitations of preferred solutions for multi-functionality problems in LCA: is increased consistency possible? International Journal of Life Cycle Assessment, v.20, pp. 74-86, 2015. https://doi.org/10.1007/s11367-014-0812-4. 
PETERS, J.; IRIBARREN, D.; DUFOUR, J. Life cycle assessment of pyrolysis oil applications. Biomass Conversion and Biorefinery, v. 5, n. 1, p. 1-19, 2015. https://doi.org/10.1007/s13399-014-0120-z.

PIRES, A.; CHANG, N.-B.; MARTINHO, G. Reliability-based life cycle assessment for future solid waste management alternatives in Portugal. The International Journal of Life Cycle Assessment, v. 16, n. 4, p. 316-337, 2011. https://doi.org/10.1007/s11367-011-0269-7.

PIRES, A.; MARTINHO, G. Life cycle assessment of a waste lubricant oil management system. The International Journal of Life Cycle Assessment, v. 18, n. 1, p. 102-112, 2013. https://doi.org/10.1007/s11367-012-0455-2.

PRASARA-A, J.; GRANT, T. Comparative life cycle assessment of uses of rice husk for energy purposes. The International Journal of Life Cycle Assessment, v. 16, n. 6, p. 493-502, 2011. https://doi.org/10.1007/s11367-011-0293-7.

REAP, J.; ROMAN, F.; DUNCAN, S; BRAS, B. A survey of unresolved problems in life cycle assessment. Part I. International Journal of Life Cycle Assessment, v.13, pp. 290- 300, 2008. https://doi.org/10.1007/s11367-008-0008-x.

RIDOUTT, B. et al. Water footprint of livestock: comparison of six geographically defined beef production systems. The International Journal of Life Cycle Assessment, v. 17, n. 2, p. 165-175, 2012. https://doi.org/10.1007/s11367-011-0346-y.

SAADE, M. R. M.; SILVA, M. G.; GOMES, V. Appropriateness of environmental impact distribution methods to model blast furnace slag recycling in cement making. Resources, Conservation and Recycling, v. 99, p. 40-47, 2015. https://doi.org/10.1016/j.resconrec.2015.03.011.

SAFT, R. J. Life cycle assessment of a pyrolysis/gasification plant for hazardous paint waste. The International Journal of Life Cycle Assessment, v. 12, n. 4, p. 230-238, 2007. https://doi.org/10.1065/lca2007.05.332.

SAMUEL-FITWI, B. et al. Aspiring for environmentally conscious aquafeed: comparative LCA of aquafeed manufacturing using different protein sources. Journal of Cleaner Production, v. 52, n. 0, p. 225-233, 2013. https://doi.org/10.1016/j.jclepro.2013.02.031.

Comparative life cycle assessment (LCA) of raising rainbow trout (Oncorhynchus mykiss) in different production systems. Aquacultural Engineering, v. 54, n. 0, p. 85-92, 2013. https://doi.org/10.1016/j.aquaeng.2012.12.002.

SANDIN, G. et al. Allocation in LCAs of biorefinery products: implications for results and decision-making. Journal of Cleaner Production, v. 93, n. 0, p. 213-221, 2015. https://doi.org/10.1016/j.jclepro.2015.01.013.

SAYAGH, S.; VENTURA, A.; HOANG, T.; FRANÇOIS, D.; JULLIEN, A. Sensitivity of the LCA allocation procedure for BFS recycled into pavement structures. Resources, Conservation and Recycling, v. 54, pp. 348-358, 2010.

https://doi.org/10.1016/j.resconrec.2009.08.011.

SCHARNHORST, W. et al. Environmental Assessment of End-of-Life Treatment Options for a GSM 900 Antenna Rack (12 pp paper version/18 pp online version). The International Journal of Life Cycle Assessment, v. 11, n. 6, p. 425-436, 2006/11/01 2006. ISSN 0948-3349. http://dx.doi.org/10.1065/lca2005.08.216.

SCHMIDT, J. Comparative life cycle assessment of rapeseed oil and palm oil. The International Journal of Life Cycle Assessment, v. 15, n. 2, p. 183-197, 2010. https://doi.org/10.1007/s11367-009-0142-0.

SCHMIDT, J. H.; WEIDEMA, B. P. Shift in the marginal supply of vegetable oil. The International Journal of Life Cycle Assessment, v. 13, n. 3, p. 235-239, 2007. https://doi.org/10.1065/lca2007.07.351.

SCHRIJVERS, D. L.; LOUBET, P.; SONNEMANN, G. Developing a systematic framework for consistent allocation in LCA. International Journal of Life Cycle Assessment, v. 21, pp. 976-993, 2016. https://doi.org/10.1007/s11367-016-1063-3.

SHONNARD, D. R. et al. A Review of Environmental Life Cycle Assessments of Liquid Transportation Biofuels in the Pan American Region. Environmental Management, v. 56, n. 6, p. 1356-1376, 2015. https://doi.org/10.1007/s00267-015-0543-8.

SIEGL, S.; LAABER, M.; HOLUBAR, P. Green Electricity From Biomass, Part I: Environmental Impacts of Direct Life Cycle Emissions. Waste and Biomass Valorization, v. 2, n. 3, p. 267-284, 2011. https://doi.org/10.1007/s12649-011-9077-3. 
Green Electricity from Biomass, Part II: Environmental Impacts Considering Avoided Burdens from Replacing the Conventional Provision of Additional Functions. Waste and Biomass Valorization, v. 3, n. 1, p. 1-21, 2012. https://doi.org/10.1007/s12649-011-9091-5.

SILVA, D. et al. Do wood-based panels made with agro-industrial residues provide environmentally benign alternatives? An LCA case study of sugarcane bagasse addition to particle board manufacturing. The International Journal of Life Cycle Assessment, v. 19, n. 10, p. 1767-1778, 2014. https://doi.org/10.1007/s11367-014-0776-4.

SLADE, R.; BAUEN, A.; SHAH, N. The greenhouse gas emissions performance of cellulosic ethanol supply chains in Europe. Biotechnology for Biofuels, v. 2, n. 1, p. 1-19, 2009. https://doi.org/10.1186/1754-6834-2-15.

SPUGNOLI, P.; DAINELLI, R. Environmental comparison of draught animal and tractor power. Sustainability Science, v. 8, n. 1, p. 61-72, 2013. https://doi.org/10.1007/s11625-012-0171-7.

SREEJITH, C.; MURALEEDHARAN, C.; ARUN, P. Life cycle assessment of producer gas derived from coconut shell and its comparison with coal gas: an Indian perspective. International Journal of Energy and Environmental Engineering, v. 4, n. 1, p. 1-22, 2013. https://doi.org/10.1186/2251-6832-4-8.

SUH, S.; YANG, Y. On the uncanny capabilities of consequential LCA. The International Journal of Life Cycle Assessment, v. 19, p. 1179-1184, 2014. https://doi.org/10.1007/s11367-014-0739-9.

SVANES, E.; ARONSSON, A. S. Carbon footprint of a Cavendish banana supply chain. The International Journal of Life Cycle Assessment, v. 18, n. 8, p. 1450-1464, 2013. https://doi.org/10.1007/s11367-013-0602-4.

SVANES, E.; VOLD, M.; HANSSEN, O. Effect of different allocation methods on LCA results of products from wild-caught fish and on the use of such results. The International Journal of Life Cycle Assessment, v. 16, n. 6, p. 512-521, 2011a. https://doi.org/10.1007/s11367-011-0288-4.

Environmental assessment of cod (Gadus morhua) from autoline fisheries. The International Journal of Life Cycle Assessment, v. 16, n. 7, p. 611-624, 2011b. https://doi.org/10.1007/s11367-011-0298-2.

THOMASSEN, M. et al. Attributional and consequential LCA of milk production. The International Journal of Life Cycle Assessment, v. 13, n. 4, p. 339-349, 2008. https://doi.org/10.1007/s11367-008-0007-y.

THRANE, M. LCA of Danish Fish Products. New methods and insights (9 pp). The International Journal of Life Cycle Assessment, v. 11, n. 1, p. 66-74, 2006. https://doi.org/10.1065/lca2006.01.232.

TILLMAN, A-M.; EKVALL, T.; BAUMANN, H.; RYDBERG, T. Choice of system boundaries in life cycle assessment. Journal of Cleaner Production, v.2, pp. 21-29, 1994. https://doi.org/10.1016/0959-6526(94)90021-3.

TILLMAN, A-M. Significance of decision-making for LCA methodology. Environmental Impact Assessment Review, v. 20, p. 113-123, 2000. https://doi.org/10.1016/S0195-9255(99)00035-9.

TONIOLO, S. et al. Comparative LCA to evaluate how much recycling is environmentally favourable for food packaging. Resources, Conservation and Recycling, v. 77, n. 0, p. 61-68, 2013. https://doi.org/10.1016/j.resconrec.2013.06.003.

TSIROPOULOS, I. et al. Life cycle assessment of sugarcane ethanol production in India in comparison to Brazil. The International Journal of Life Cycle Assessment, v. 19, n. 5, p. 1049-1067, 2014. https://doi.org/10.1007/s11367-014-0714-5.

VAN DER WERF, H. G.; NGUYEN, T. Construction cost of plant compounds provides a physical relationship for co-product allocation in life cycle assessment. The International Journal of Life Cycle Assessment, v. 20, n. 6, p. 777-784, 2015. https://doi.org/10.1007/s11367-015-0872-0.

VÁZQUEZ-ROWE, I. et al. Applying consequential LCA to support energy policy: Land use change effects of bioenergy production. Science of The Total Environment, v. 472, n. 0, p. 78-89, 2014. https://doi.org/10.1016/j.scitotenv.2013.10.097.

WARDENAAR, T. et al. Differences between LCA for analysis and LCA for policy: a case study on the consequences of allocation choices in bio-energy policies. The International Journal of Life Cycle Assessment, v. 17, n. 8, p. 1059-1067, 2012. https://doi.org/10.1007/s11367-012-0431-x. 
WEIDEMA, B. P. Avoiding co-product allocation in life cycle assessment. Journal of Industrial Ecology, v.4, pp. 11-33, 2001. https://doi.org/10.1162/108819800300106366.

WEIDEMA, B. P.; SCHMIDT, J. H. Avoiding allocation in life cycle assessment revisited. Journal of Industrial Ecology, v. 14, n. 2, p. 192-195, 2010. https://doi/10.1111/j.1530-9290.2010.00236.x.

WERNER, F. et al. Post-consumer waste wood in attributive product LCA. The International Journal of Life Cycle Assessment, v. 12, n. 3, p. 160-172, 2007. https://doi.org/10.1065/lca2006.05.249.

WIEDEMANN, S. et al. Application of life cycle assessment to sheep production systems: investigating co-production of wool and meat using case studies from major global producers. The International Journal of Life Cycle Assessment, v. 20, n. 4, p. 463476, 2015. https://doi.org/10.1007/s11367-015-0849-z.

WILOSO, E.; BESSOU, C.; HEIJUNGS, R. Methodological issues in comparative life cycle assessment: treatment options for empty fruit bunches in a palm oil system. The International Journal of Life Cycle Assessment, v. 20, n. 2, p. 204-216, 2015. https://doi.org/10.1007/s11367-014-0815-1.

WOHLIN, C. Guidelines for snowballing in systematic literature studies and a replication in software engineering. In: International Conference on Evaluation and Assessment in Software Engineering, 18, 2014. London. Proceedings... New York: ACM, 2014. p. $1-10$.

XIE, M. et al. Life cycle assessment of composite packaging waste management - a Chinese case study on aseptic packaging. The International Journal of Life Cycle Assessment, v. 18, n. 3, p. 626-635, 2013. https://doi.org/10.1007/s11367-012-0516-6.

ZAIMES, G. G.; KHANNA, V. The role of allocation and coproducts in environmental evaluation of microalgal biofuels: How important? Sustainable Energy Technologies and Assessments, v. 7, n. 0, p. 247-256, 2014.

https://doi.org/10.1016/j.seta.2014.01.011.

ZAMAN, A. U. Comparative study of municipal solid waste treatment technologies using life cycle assessment method. International Journal of Environmental Science \& Technology, v. 7, n. 2, p. 225-234, 2010. https://doi.org/10.1007/BF0332613.

ZAMPORI, L.; DOTELLI, G. Design of a sustainable packaging in the food sector by applying LCA. The International Journal of Life Cycle Assessment, v. 19, n. 1, p. 206-217, 2014. https://doi.org/10.1007/s11367-013-0618-9.

ZIMMERMANN, A. et al. Are public payments for organic farming cost-effective? Combining a decision-support model with LCA. The International Journal of Life Cycle Assessment, v. 16, n. 6, p. 548-560, 2011. https://doi.org/10.1007/s11367-0110286-6.

\footnotetext{
${ }^{1}$ Marcella Ruschi Mendes Saade

Engenheira Ambiental. Doutora em Engenharia Civil. Pesquisadora colaboradora do Departamento de Arquitetura e Construção, Faculdade de Engenharia Civil, Arquitetura e Urbanismo, Universidade Estadual de Campinas. Endereço Postal: Rua Saturnino de Brito, 224, Campinas, SP, Brasil, 13083-889
}

\author{
${ }^{2}$ Maristela Gomes da Silva \\ Engenheira Civil. Doutora. Professora Titular do Departamento de Engenharia Civil da Universidade Federal do Espírito Santo. \\ Endereço Postal: Avenida Fernando Ferrari, S/N, Vitória, ES, Brasil, 29075-010

\section{${ }^{3}$ Vanessa Gomes da Silva} \\ Arquiteta. Doutora. Professora Associada livre-docente na Faculdade de Engenharia Civil, Arquitetura e Urbanismo da \\ Universidade Estadual de Campinas. Endereço Postal: Rua Saturnino de Brito, 224, Campinas, SP, Brasil, $13083-889$
}

